\section{The environmental dimension in the context of the operations strategy of the São Paulo's ABC region automotive manufacturers}

\author{
Gabriela Scur ${ }^{1}$ \\ Guilherme Heinz ${ }^{1}$ \\ ${ }^{1}$ University Center FEI, Department of Industrial Engineering, \\ Sao Bernardo do Campo, SP, Brazil
}

Received on

10/10/2014

Approved on

05/24/2016

\section{Responsible editor:}

Prof. Dr. João Maurício Gama

Boaventura

Evaluation process:

Double Blind Review

\begin{abstract}
Purpose - This paper aims to analyze the insertion of the environmental dimension in the operations strategy of three automotive manufacturers belonging São Paulo's ABC region, and how it can impact the operations field's competitive performance.
\end{abstract}

Design/methodology/approach - Descriptive, exploratory multiple case study.

Findings - There is an alignment between companies with regard to the performance indicators of the environmental dimension and to competitive priorities. We observed concern as to the social aspect of sustainability. Companies are designing socially fair production systems, in which work safety and occupational health are seen as strategic factors that contribute to competitive performance in the field of operations.

Originality/value - One theoretical contribution is the proposal of a conceptual model that aims to fill a gap in literature concerning the lack of alignment between the operations strategy and environmental management, which can, in turn, hinder or even underestimate the understanding of the role of the operations field in the quest for competitive advantage.

Keywords - Operations strategy; competitive priorities; environmental dimension; automotive industry; performance indicators.

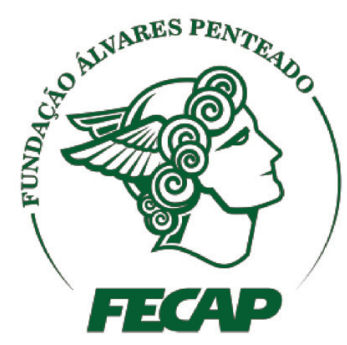

Review of Business Management

DOI: $10.7819 /$ rbgn.v18i60.2195 


\section{Introduction}

Within the scope of corporate management, it is corporate or business strategy which dictates how companies intend to achieve, maintain and expand competitive advantages, thus involving all the company's long-term management aspects (Barnes, 2002; Hayes \& Wheelwright, 1984). The corporate strategy of companies that are committed to sustainability must involve the adoption of environmental policies that, by their turn, have an impact on a company's operational performance (Jabbour et al., 2012). In this context, the operations field has a significant impact on competitiveness (Skinner, 1969; Voss, 2005) because it is responsible for liaising market needs to the operations resources (Slack \& Lewis, 2001).

Jimenez \& Lorente (2001) claim that, to achieve competitive advantage in a sustainable way, an operations strategy must consider the environmental dimension as an additional dimension alongside the traditional dimensions of cost, quality, reliability and flexibility. Indeed, we can find synergy between the environmental protection programs and production methods and techniques, since programs to control pollution, minimize waste and DfE are capable of improving traditional operation management techniques such as statistical process control, lean production and total quality management. Therefore, it is necessary to expand the performance assessment coverage in the operations field, as well as support main operational decisions towards environmental performance. According to Angell \& Klassen (1999) and Jimenez \& Lorente (2001), including environmental performance as a competitive priority is expected to be the first step towards a sustainable strategic management.

Although certain studies (Angell \& Klassen, 1999; Alfred \& Adam, 2009, Gupta 1995) associate these two topics, especially in developed countries, we observe a lack of theoretical-empirical studies in companies in Brazil. Therefore, considering operations strategy and the environmental dimension, the research question involves understanding how companies consider the environmental dimension in their operations strategy, and understanding its impact on operations' competitive performance. Thus, the objective of the article is to assess the insertion of the environmental dimension in automotive companies' operations strategies, and how it can impact the competitive performance of the operations field.

This article is divided into six sections; the first is this introduction. Section 2 deals with the operations strategy theory, which discusses competitive advantage and presents the authors' perspective on the operations strategy formulation and contents, also including considerations about operations strategy. The environmental dimension is discussed in section 3 , beginning with the evolution of the environmental issue and emphasizing the growing importance of this topic to companies, finally detailing environmental performance and its main indicators. Section 4 presents the research method, the conceptual research model, the set of indicators used in analyzing the data and also the definition of the companies that participated in this multiple case study, alongside data collection tools. The research results are presented in section 5 . The last section, 6 , discloses the final considerations of the study.

\section{Operations strategy and the environmental dimension}

An operations strategy is the combination of several organizational decisions and actions that have an impact in the long term (Barnes, 2002). In order to establish competitive advantage, a strategy must contain a set of plans and policies to enable the company to achieve advantages over its competitors (Skinner, 1969). These plans and policies may present different characteristics depending on the strategy level, whether corporate, tactic or operational. 
The functional strategy arises from the development of the business strategy, and defines how the function, whether sales and marketing, operations, research and development, financial or quality, will support competitive advantage, and how it will complement other functional strategies (Hayes \& Wheelwright, 1984; Silva, 2008). Therefore, in terms of strategic planning, the operations strategy is a functional strategy, and provides support to a company's competitive strategy (Maia et al., 2005). The first author to create the concept of operations strategy, known in that time as manufacturing strategy, was William Skinner. Skinner (1969) defined it as the operations policies derived from the corporate or business strategy that define the scope of the operations process, the scale of the operations process, the choice of the operations process and equipment, plant localization, the establishment of critical control elements, control systems and the organization of management.

According to Hayes \& Wheelwright (1984), the main function of an operations strategy is to develop a set of operations capacities that will allow the business to accomplish its present and future strategy. Above all, the operations strategy has the purpose of combining market requirements and the organization's resources (Voss, 1995).

Among the several concepts about the contribution of the operations field to competitiveness, there is the one concerning competitive priorities that refers to competitive dimensions, initially mapped by Skinner (1969) as productivity, service, quality and return on investment. Later, other authors presented new priorities, such as product prices; better quality; reliability; and product flexibility and volume, which are all assigned different priorities by companies, depending on the market's situation and on the production system (Hayes \& Wheelwright, 1984).

An operations strategy reflects the demand trend as a reaction of the company to the market, and competitive priorities as a proactive response.
Therefore, since it is a proactive response, competitive priorities have become a key element in the operations strategy, which defines which dimensions the operations field must proactively, effectively and efficiently carry out.

As to the evolution and adequacy of the operations strategy, Hayes \& Pisano (1996) state that it is no longer made up of tradeoffs between competitive priorities such as cost, quality, delivery and flexibility. Long-term success requires the company to differentiate itself from its competitors by offering something unique and valuable to its customers, such as services that are quick and highly reliable, low-cost or innovative.

Also expanding the traditional perspective of competitive priorities, several authors (Angell \& Klassen, 1999, Alfred \& Adam, 2009, Jimenez \& Lorente, 2001, Gravonski, 2012) started to consider the environmental dimension as a competitive priority, because to mitigate the environmental impact is, in large part, the responsibility of operations management (Jimenez \& Lorente, 2001). As a matter of fact, although the pressure of stakeholders, environmental legislation, financial benefits, company image and top management commitment is capable of motivating the adoption of environmental practices (Govidan et al., 2014; Hsu et al., 2013 and Srivastava, 2007), there is a positive relationship between environmental management and the operational performance of companies. According to Alfred \& Adam (2009) and Jabbour et al. (2012), environmental management attempts to maximize the productivity of supplies, reduce costs and maximize organizational resources.

In the corporate environment and, particularly, in the industrial environment, the environmental dimension can be related to the direct environmental impact caused by the product and by the production process, and also by the indirect impact that affects the supply chain (Sanches, 2000). The environmental impact caused by the product is due to the volume and type of raw materials and energy used, and to its use 
during its lifetime, such as power consumption, fuel consumption and emissions; also including its final disposal. The environmental impact caused by the production process is due to the consumption of raw materials; consumption of water and energy; waste generation; pollution of the air, water and soil; and the final disposal of waste, particularly when hazardous (Sarkis, 2001).

According to Jimenez \& Lorente (2001), in order to include another dimension to traditional competitive priorities, the company has to meet two requirements. The first is that it should be linked to the operations function, and the second is offering a competitive advantage. In this case, the environmental dimension's impact is measured by operational performance indicators and can, therefore, provide a competitive advantage if well managed.

According to Jimenez \& Lorente (2001) and Angell \& Klassen (1999), the environmental dimension qualifies the manufacturing process, and is measured by sets of environmental performance indicators. According to the authors, there are four sets: (1) consumption of natural resources and energy, (2) compliance with legislation and standards, (3) prevention of environmental impacts and pollution and (4) fulfillment of society demands.
Environmental performance indicators have the purpose of demonstrating the organizational practices used to minimize impacts on the environment arising from the company's activities.

In order to standardize the definition of performance indicator sets, ISO 14031 can be used as guidance (ABNT, 2004; Campos \& Melo, 2008; Jacobs et al., 2010). Although environmental impacts may vary according to the type of company, the standard contains a set of common indicators that can be used for environmental performance analysis of the operations.

Consequently, the environmental performance indicators to be used in this study were based on the performance indicators of the standard ISO 140031:2004, since these indicators are focused on production processes. They are as follows: use of materials, raw materials, hazardous materials and the consumption of water and energy, generation of waste and general emissions, and operations support services, which are also considered good environmental practices.

The breakdown of the attributes of the environmental dimension factors into environmental performance indicators can be seen in Table 1.

\section{Table 1}

\section{Breakdown of environmental performance indicators}

\begin{tabular}{ll}
\hline $\begin{array}{l}\text { Set of indicators } \\
\text { (Factors) }\end{array}$ & $\begin{array}{l}\text { Detailed indicators } \\
\text { (Attributes) }\end{array}$ \\
\hline consumption of natural resources and energy & Consumption of energy and water \\
\hline Legal compliance & $\begin{array}{l}\text { Awarding of environmental licenses } \\
\text { Compliance with Brazilian standards }\end{array}$ \\
\hline Prevention of impacts & $\begin{array}{l}\text { Generation of waste and emissions } \\
\text { Cleaner production (P+L) }\end{array}$ \\
& Environmental management system \\
& Environmental performance index \\
& Selective waste collection \\
\hline Society's demands & Questions/information about sustainability \\
& Prevention of impacts \\
& Legal compliance \\
\hline
\end{tabular}


According to Lowson (2003), the operations strategy's performance can be interpreted by the performance of strategic practices such as global standard manufacturing, lean production, strategic outsourcing, manufacturing per order/ manufacturing for stock and supplier network management. These practices, in turn, are measured by performance indicators with respect to competitive priorities such as quality, delivery, flexibility, cost, and image performance. According to Thomas \& Brito (2010), the indicator that measures image is environmental responsibility.

Based on the literature review, a conceptual model was prepared, as shown in Figure 1, considering that the environmental demands originated by society, the legislation and the market, which impact and influence the environmental dimension (DA), which, in turn, must be considered by the business or competitiveness strategy (EN), are used by the company in the preparation of its environmental policy (PMA). The operations strategy (EO), whether considering or not the environmental policy (PMA) in the breakdown of the (1) business strategy, represents the company's strategic option. This strategic option, when detailed (2) down to the operational level, may affect in either a positive or negative way the competitive performance of the operations (DO) by means of the operations management (GO) that incorporates environmental management and the environmental management system (ISO), also affecting mainly the company's competitive priority cost and image. The above may bring an improvement opportunity to the competitive performance of the operations (DO) with respect to meeting market demands, to offering cheaper and better products and services with less environmental impact and with an improved image due to environmentally appropriate manufacturing, service and products.

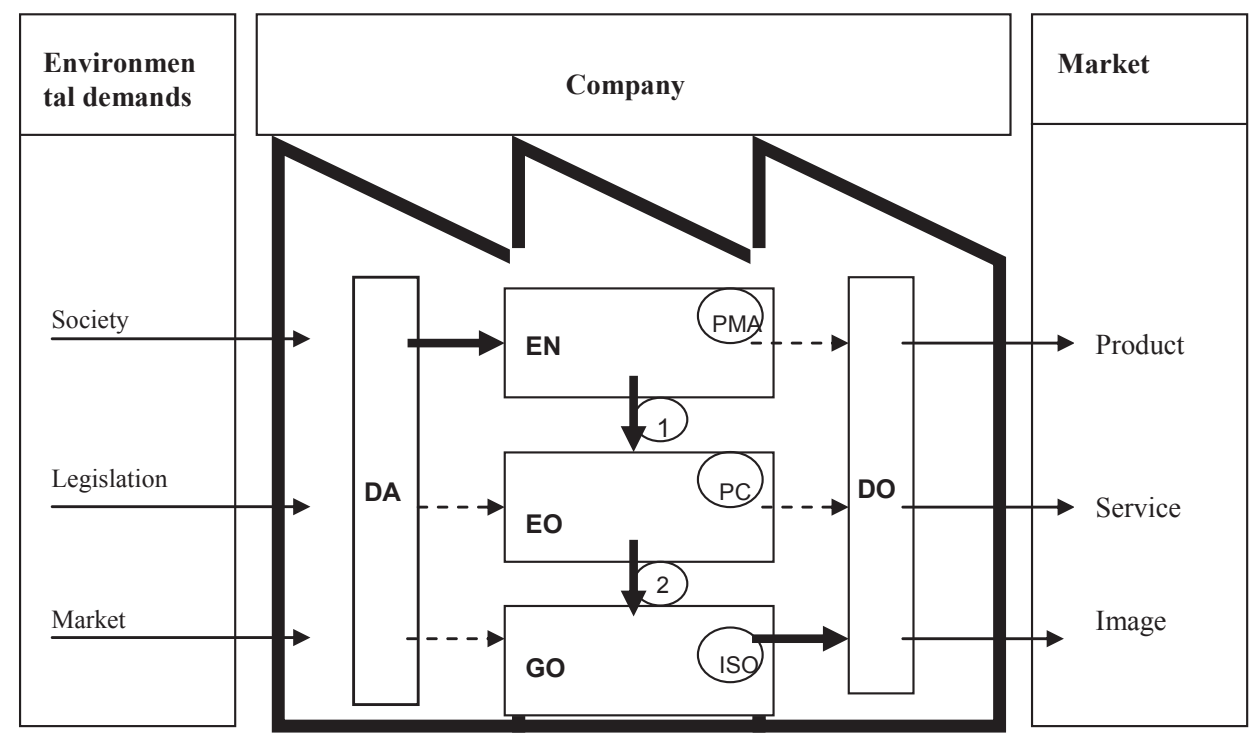

Figure 1. Conceptual Research Model

There are six constructs in the conceptual model: (1) External Environmental Demands, (2) Environmental Dimension, (3) Environmental Policy, (4) Competitive Priorities, (5) Operation
Performance and (6) Market Demands. Table 2 presents these constructs and the respective authors who discuss each one. 
Table 2

\section{Constructs}

\begin{tabular}{|c|c|}
\hline Construct & Authors \\
\hline External Environmental Demands & $\begin{array}{l}\text { Govidan et al. (2014) } \\
\text { Hsu et al. (2013) } \\
\text { Srivastava, } 2007\end{array}$ \\
\hline Environmental Dimension (DA) & $\begin{array}{l}\text { Jimenez \& Lorente (2001) } \\
\text { Angell \& Klassen (1999) }\end{array}$ \\
\hline Environmental Policy (PMA) & $\begin{array}{l}\text { Campos \& Melo (2008) } \\
\text { Jacobs et al. (2010) }\end{array}$ \\
\hline Competitive Priorities (PC) & $\begin{array}{l}\text { Skinner (1969) } \\
\text { Hayes \& Wheelwright (1984) } \\
\text { Angell \& Klassen (1999) } \\
\text { Alfred \& Adam (2009) } \\
\text { Jimenez \& Lorente (2001) } \\
\text { Gravonski (2012) }\end{array}$ \\
\hline Operation Performance (DO) & $\begin{array}{l}\text { Alfred \& Adam (2009) } \\
\text { Jabbour et al. (2012) }\end{array}$ \\
\hline Market Demands & $\begin{array}{l}\text { Lowson (2003) } \\
\text { Thomas \& Brito (2010) }\end{array}$ \\
\hline
\end{tabular}

Source: The authors

Analysis of these six constructs allows for understanding of the insertion of the environmental dimension in the operations strategy of automakers and how it can impact the competitive performance of operations.

\section{Methodological procedures}

Considering that the objectives of a study determine the strategy, the type and the method of research to be applied, and since this research's objective was defined as analysis of the environmental dimension's insertion in the operations strategy, and its impact on the competitive performance of the operations field, a multiple, descriptive and exploratory case study was chosen (Gil, 1999; Ventura, 2002). According to Yin (2007), the essence of a case study is the fact that it tries to shed light on a decision or on a set of decisions: why they were taken, how they were implemented and what were the results obtained.

Criticism regarding the chosen method refers mainly to the impossibility of generalizing results. On the other hand, the method allows the assessment of theoretical generalizations that can be improved by carrying out more than one case study (Collis et al., 2003; Voss et al., 2002).

The companies participating in the study belong to the automotive sector, more specifically automotive manufacturing companies. The choice of the sector derives from the fact that the environmental impacts caused by the waste of cars and trucks are relevant, and also because the industrial sector was responsible for presenting the largest number of implementations of good environmental practices according to the 2010 Annual Report of the Environmental Management Analysis, published by the Analyze Publishing House. Therefore, three automotive companies of the São Paulo's ABC region were selected, considering that all of them manage the environmental dimension with the help of a certified environmental management system (ISO 14001); one is an automotive manufacturing company of American origin (A), another of European origin (E) and the last of Asian origin (J), therefore representing the main cultures present in the automotive industry, thus allowing for better coverage.

The study was carried out with the help of encompassing face-to-face interviews 
supplemented by documents and reports provided by the companies, a list of questions and also by direct observation (Voss et. al., 2002).

The documentation was obtained from company sites, internal and external publications, reports and specialized magazines and allowed the preparation of a company history considering its line of products, technical specifications, market share, organization and hierarchical structure, which composed the initial context for the case analysis.

A question list containing twenty-one questions about environmental performance, was previously sent by mail and e-mail, with the purpose of gathering information about environmental indicators, provide support for the interviews and also for the gathering of comparative data regarding the three companies.

Seventeen hour and a half-long face-toface interviews were carried out and recorded, involving the managers responsible for the fields of operations, environment, quality, production, logistics, infrastructure and industrial planning, in the three selected companies, therefore characterizing a sampling based on convenience and not probability. The data collection took place in the period from January to April, 2011.

The data collection system consisted of a semi-structured interview script composed by eleven questions about how the incorporation of the environmental dimension into the operations strategy took place and how the environmental dimension has impacted the competitive performance of operations.

Regardless of the relevance of the product on the environmental impact of a company, this study considered only the environmental impact of the process, because it is directly related to the operations strategy.

The data analysis was carried out first based on a conceptual model composed by six analysis elements, which are as follows: external environmental demands, environmental dimension, environmental policy, competitive priorities, operations performance and market requirements. Later, a cross-check was carried out involving environmental dimension, operations strategy and competitive priorities, in order to validate the conceptual model. Each person interviewed attributed one point for a medium or strong inter-relationship and zero point for the absence of or a weak inter-relationship between the environmental dimension and the operations strategy, the competitive priorities and the company image.

\section{Presentation and discussion of the results}

\section{I Results of the model dimensions}

\section{I.I External environmental demands}

The companies involved in the study, regardless of their cultural origin, have adopted the same content as external environmental demand, thus interpreting that society is concerned with the consumption of natural resources and the spreading of pollution. The legal demands, both regarding the literature and the interpretation of the companies, are linked to legal compliance, which, in the case of the three companies, translates equally in the compliance with the environmental licenses, regulating standards and environmental laws.

The market environmental demands, presented by the literature, refer to the concern of the customers for a low environmental impact of the company's products and processes. The three companies involved in the study, by their turn, have considered the market environmental demands as those leading to the generation of the lowest possible environmental impact.

We can conclude that, in the case of environmental demands, both the academic sector and the practices of the three companies confirm the conceptual model proposed for the research, which is composed by society's external demands, legislation and market; thus, we can say that the companies involved in the study, 
regardless of their cultural origin, have adopted the environmental demands in the same way and with the same content.

\subsubsection{Environmental dimension}

The composition of the companies' environmental dimension consists of a set of impacts that the operational processes of these companies may cause to the environment, taking in consideration the environmental demands of society, the legislation and the market. This means that, in the case of society's demand for sustainability, the company's environmental dimension is measured by the consumption of natural resources and energy and the prevention of environmental impacts. In the case of legal demands, the legal compliance was present, and in the case of the market demand, once more the prevention of environmental impacts was predominant.

Table 3 presents the composition of the companies' environmental dimension that, by its turn, agrees with the literature.

Table 3

\section{Composition of the environmental dimension}

\begin{tabular}{|c|c|}
\hline Companies & Composition of the environmental dimension \\
\hline European (E) & $\begin{array}{l}\text { Consumption of natural resources } \\
\text { Compliance with the legislation and standards } \\
\text { Prevention of environmental impacts } \\
\text { Fulfillment of society's demands }\end{array}$ \\
\hline American (A) & $\begin{array}{l}\text { Consumption of natural resources } \\
\text { Compliance with the legislation } \\
\text { Prevention of environmental impacts }\end{array}$ \\
\hline Japanese (J) & $\begin{array}{l}\text { Consumption of natural resources and energy } \\
\text { Compliance with the legislation and standards Prevention of environmental impacts } \\
\text { and pollution } \\
\text { Fulfillment of society's demands }\end{array}$ \\
\hline LITERATURE & $\begin{array}{l}\text { Consumption of natural resources and energy } \\
\text { Compliance with the legislation and standards } \\
\text { Prevention of environmental impacts and pollution } \\
\text { Fulfillment of society's demands }\end{array}$ \\
\hline
\end{tabular}

It can also be noted a strong alignment between the companies and the literature, suggesting a possible pattern for the automotive sector, thus confirming a statement by Womack $\&$ Jones (2004) that says that this sector is one of the most appropriate for an analysis of emerging organizational trends.

\section{I.3 Environmental policy}

The environmental policy defined by the corporate or business strategy, as detailed for the operations strategy, defines the company's strategic options in considering the environmental dimension and how it will be put in place by operations management.

The environmental policies of the companies are shown in Table 3 and present common elements as legal compliance, prevention of environmental impacts and fulfillment of society's demands. 
Table 4

Summarized environmental policies of the companies under study

\begin{tabular}{ll}
\hline Companies & Environmental policy \\
\hline European (E) & $\begin{array}{l}\text { Fulfillment of future demands and ongoing improvement, product development } \\
\text { and planning of environmentally responsible processes, legal compliance, services } \\
\text { and information to customers focused on environmental preservation and corporate } \\
\text { management. }\end{array}$ \\
\hline American (A) & $\begin{array}{l}\text { Business decisions considering the environment, legal compliance, products, } \\
\text { environmentally adequate planned processes and services, objectives for minimizing impacts } \\
\text { on the environment, environmental protection as the responsibility of all employees. }\end{array}$ \\
\hline Japanese (J) & $\begin{array}{l}\text { Legal compliance, fulfillment of stakeholder's requirements, prevention of environmental } \\
\text { impacts, continuously improved environmental performance, employee training. }\end{array}$ \\
\hline
\end{tabular}

These elements are in line with the composition of the environmental dimension, except in the aspect of the reduction in the consumption of natural resources and energy, which could be considered a consequence of the element of fulfillment of society's demands, as a result of sustainability. In any way, we can also perceive here an alignment among the companies.

\section{I.4 Competitive priorities}

The competitive priorities are a key element of the operations strategy that, by its turn, define which operational tasks must be proactively, efficiently and effectively carried out.

In addition to the priorities considered in the theory, the companies have defined the environmental and occupational safety priorities.

Among the competitive priorities, the cost was the most affected by the environmental dimension, because it means manufacturing products with the lowest cost possible, being the most significant costs generated by costs with personnel, installations, technology, raw material, consumption materials, natural resources and the treatment and disposal of waste and effluents.

\section{I.5 Operations performance}

By incorporating the environmental dimension as a competitive priority of the operations strategy, the companies have abated production process planning reworks solely by means of investment on and acquisition of new equipment environmentally more adequate, thus avoiding later modifications intended to meet environmental or legal requirements.

The operational performance was measured using environmental impact indicators applied to the manufacturing processes of these companies based on the ISO 14031 standard, which are: water consumption, energy consumption, waste generation and recycling degree (rate in percentage between recycled waste and generated waste).

The average accumulated performance of the reduction in the consumption of water and energy and the generation of waste per vehicle produced by the companies in the last three years was of: $15 \%, 10 \%, 20 \%$ and $92 \%$ of recycling, respectively. This means an actual cost reduction with the consumption of resources and disposal of waste in the manufacturing process, resulting in lower prices or higher margins.

Another aspect positively affected by the environmental performance was the company's institutional image, which led to an improvement in the performance of one of its indicators, environmental responsibility that, by means of an environmentally adequate manufacturing, is able to meet the growing demand of society for a consistent contribution of the industry towards sustainability, particularly regarding the environmental aspect.

\subsubsection{Market requirements}

In the question about the identification of the market demand, in addition to legal 
compliance, there was the demand of dealers and customers. However, some of the persons interviewed have stated that the customers are still only concerned with price. Although this is a reality, the companies have taken proactive actions in dealing with the environmental dimension, because they feel that the customer's view may quickly change.

Figure 2 presents the conceptual model with the main results found.

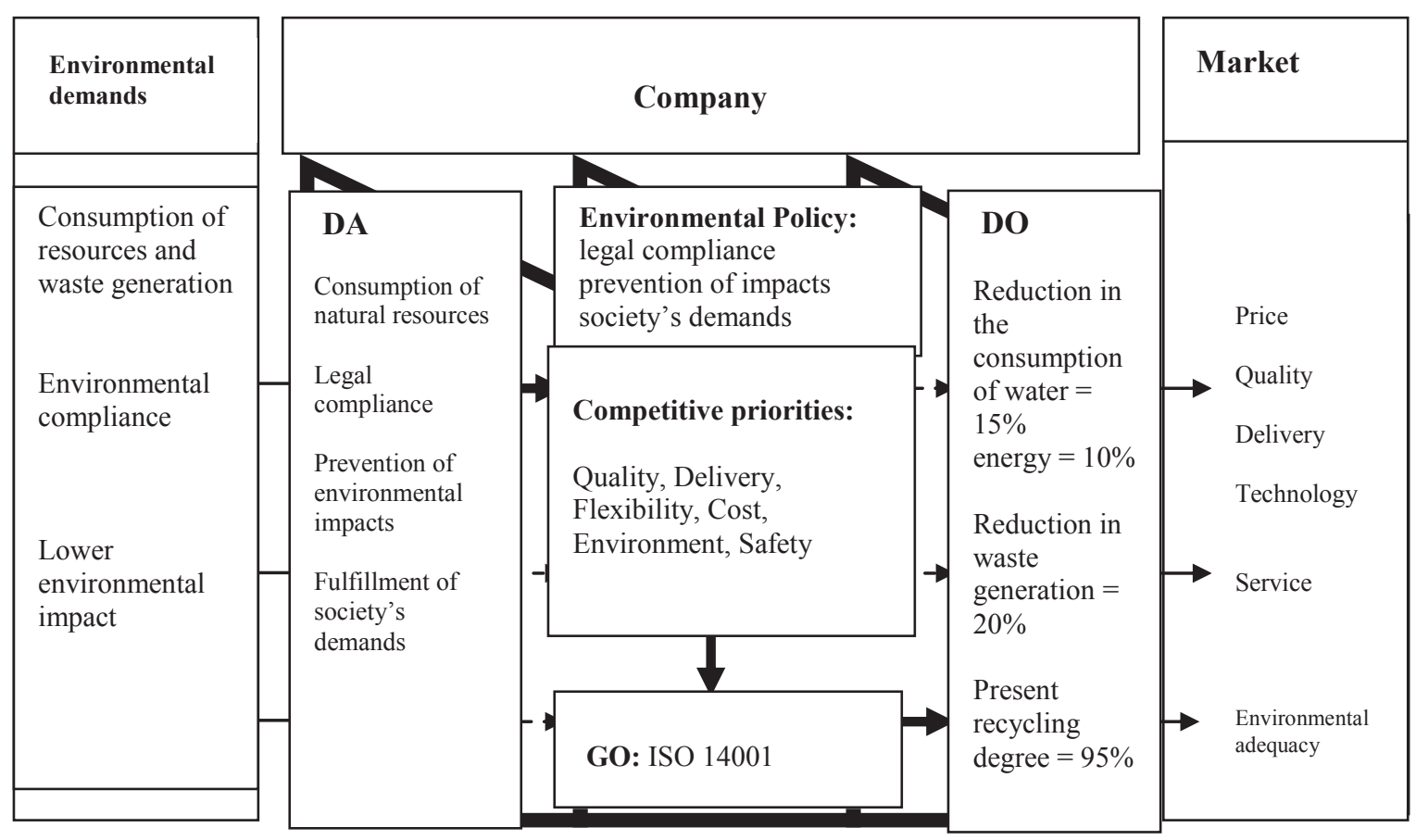

Figure 2. Conceptual model of the research with consolidated data of the researched companies

In Figure 2 it is possible to note the relationship between the external environmental demands and the environmental dimension composition - DA that breaks down into the environmental policy - PMA of the business strategy - EN. By its turn, business strategy - EN is translated into the competitive priorities $\mathrm{PC}$ of the operations strategy EO.

The internal environmental management system (ISO 14001) improves the competitive performance of operations - DO through the reduction in the consumption of water and energy, the generation of waste per vehicle produced in the last three years and the degree of recycling. Finally, the market requirements of each company are presented.

\subsection{Confirmation of the model}

The consolidated result of the interrelation of the environmental dimension and the operations strategies, the competitive priorities and the image of the companies is presented in Table 5. 
Table 5

Interrelations of the environmental dimension

\begin{tabular}{|c|c|c|c|c|c|c|c|c|c|c|}
\hline \multirow{2}{*}{\multicolumn{2}{|c|}{$\begin{array}{l}\text { Environmental dimension } \\
\text { Lean production }\end{array}$}} & \multicolumn{4}{|c|}{ Operations strategy } & \multicolumn{3}{|c|}{ Competitive priorities } & \multirow[t]{2}{*}{ Others } & \multirow[t]{2}{*}{ Total } \\
\hline & & outsourcing & $\begin{array}{l}\text { Supplier } \\
\text { network }\end{array}$ & $\begin{array}{l}\text { BTO/ } \\
\text { BTS }\end{array}$ & Cost & Quality & Delivery & Image & & \\
\hline \multirow{2}{*}{$\begin{array}{l}\text { Reduction in the } \\
\text { consumption of } \\
\text { natural resources }\end{array}$} & Water & 17 & 14 & 6 & 6 & 17 & 3 & 3 & 15 & 81 \\
\hline & Energy & 17 & 14 & 7 & 10 & 17 & 4 & 4 & 16 & 89 \\
\hline \multirow{2}{*}{$\begin{array}{l}\text { Compliance } \\
\text { with Laws and } \\
\text { Standards }\end{array}$} & Licenses & 14 & 7 & 9 & 4 & 13 & 7 & 13 & 16 & 83 \\
\hline & Standards & 14 & 7 & 10 & 5 & 11 & 13 & 12 & 17 & 89 \\
\hline \multirow{5}{*}{$\begin{array}{l}\text { Prevention of } \\
\text { Impacts }\end{array}$} & $\begin{array}{l}\text { Reduction in the } \\
\text { Generation of } \\
\text { Waste }\end{array}$ & 17 & 11 & 8 & 4 & 17 & 7 & 3 & 17 & 84 \\
\hline & $\mathrm{P}+\mathrm{L}$ & 17 & 7 & 7 & 4 & 14 & 13 & 6 & 17 & 85 \\
\hline & SGA & 16 & 5 & 10 & 6 & 11 & 6 & 6 & 17 & 77 \\
\hline & IDA & 16 & 9 & 5 & 5 & 14 & 6 & 4 & 16 & 75 \\
\hline & $\begin{array}{l}\text { Selective } \\
\text { collection }\end{array}$ & 17 & 8 & 6 & 3 & 16 & 4 & 3 & 17 & 74 \\
\hline \multirow{3}{*}{$\begin{array}{l}\text { Society's } \\
\text { demands }\end{array}$} & Sustainability & 17 & 9 & 11 & 3 & 13 & 8 & 9 & 17 & 87 \\
\hline & $\begin{array}{l}\text { Prevention of } \\
\text { impacts }\end{array}$ & 15 & 10 & 8 & 3 & 13 & 8 & 6 & 17 & 80 \\
\hline & $\begin{array}{l}\text { Legal } \\
\text { compliance }\end{array}$ & 15 & 9 & 12 & 2 & 13 & 7 & 11 & 17 & 86 \\
\hline \multicolumn{2}{|l|}{ Total } & 192 & 110 & 99 & 55 & 169 & 86 & 80 & 199 & \\
\hline
\end{tabular}

BTO - Build to order, BTS - Build to stock, P+L = Cleaner Production, IDA - Environmental Performance Index, SGA -Environmental Management System

The environmental dimension as a whole has a stronger interrelation with lean production and world-class manufacturing (192 points), because these strategies are guided by waste reduction and also by outsourcing (110 points), since each time more the automotive industry transfers the development of new products and components to the suppliers.

Another aspect worth mentioning is that the objectives and actions defined by the operations strategy regarding the environmental dimension have a greater impact on the competitive priority of cost (169 points) and on company image (199 points). More specifically, water and energy consumption ( 45 points on average) is the most affected of the factors, because theoretically it gets the highest attention from the companies due to its impact on cost. This result confirms the conceptual model's hypothesis that defined the competitive priority of cost and the company image as the factors most affected by the manner how the operations strategy considers the environmental dimension.

Society's demands (37 points on average), prevention of impacts (36 points on average) and compliance with laws and standards (35 points on average) are affected with equal intensity by the operations strategy. This is a result at the same time unexpected and surprising. It is unexpected because legal compliance and the prevention of impacts are expected to have greater influence as they have a direct impact on the company operations. It is surprising because it signals that society's demands are being incorporated and that the companies are following a path that leads to the implementation of more complex environmental practices, as a cleaner production and a system of internal environmental management.

When the result of the interrelations of the four environmental dimension factors 
with competitive priorities is analyzed, we can observe that the factor of compliance with laws and standards has a greater influence on the performance of the competitive priorities (34 points on average) followed by factors society's demands (29 points on average), consumption of natural resources (24 points on average) and finally the factor of prevention of impacts (21 points). This result highlights that the environmental dimension performance indicators have a strong influence on the performance of the company image, reaching $97 \%$ of the possible points and also exceeding the strong influence on the performance of the competitive priority of cost, with $83 \%$ of the possible points.

Most of the people interviewed stated that the decision of the companies to incorporate environmental dimension as a competitive priority in the operations strategy was taken because, in some cases, the intention was to improve the situation of costs, efficiency, sustainability and image and, in other cases, ensure legal compliance or simply due to commitment by the high management. An initial negative impact on the competitive performance of the operations was also mentioned, as a result of investments in new clean technologies that have temporarily increased the operational cost.

Production systems were adapted to improve the performance of environmental indicators such as energy conservation (by replacement of equipment for other more energy efficient), modification of packaging for reuse (replacement of one-way cardboard and wooden packaging for long life returnable plastic packaging), waste management (reducing hazardousness and increasing reuse) and recyclability (through the implementation of recyclable waste stations, elimination of oil leaks in equipment and machines, elimination of CFC refrigerant gas in refrigeration equipment and investment in equipment that is more environmentally adequate, with water-based painting and others).

What actually changed in competitive performance with the incorporation of environmental dimension as an operations strategy's competitive priority was a lower operational cost due to the reduction in environmental cost, as a result of the average improvement of $15 \%$ in the environmental performance indicators, and an improved image that is the consequence of an environmentally more adequate manufacturing process. Therefore, it can be noted that environmental dimension, when considered as an operations' competitive priority, can contribute for a lower operational cost, allowing the companies to either charge lower prices or take the advantage of higher margins. Additionally, it can also improve the company image and increase customer loyalty.

It remained clear that the companies are proactively adapting their processes to make them capable of fulfilling market requirements and, therefore, ensuring sustainable competitive advantage. This can be confirmed by the fact that the companies are introducing environmental dimension into their business strategies, by formulating an environmental policy based on external demands that, when broke down in operational strategies, is carried out by the environmental management with the support of the ISO 14001 standard.

\section{Final comments}

The purpose of this article is to analyze the insertion of environmental dimension into the operations strategy of car and truck assembling companies and how it can impact the competitive performance of the operations field. Therefore, a case study was conducted in three companies of the $A B C$ region, represented by 17 executives from different fields of the companies. It was ascertained that, regardless of the country of origin of the mother companies, an alignment showed up among the companies, almost a pattern, with respect to the operations strategy, the environmental demands, the environmental dimension factors, attributes and performance indicators, and the competitive priorities, regardless of the type of the company product. 
In the interrelations between the environmental dimension and the operations strategy, the competitive priorities and the company image, it was found that the environmental dimension presents a stronger interrelation with the operation strategies of lean production and outsourcing. It was also ascertained that water and energy consumption was affected with higher intensity than the other factors. Therefore, the environmental dimension performance resulting from objectives and actions defined by the operation strategies, impacts with higher intension the competitive priority of cost and the company image.

In the interrelations of the four environmental dimension factors with the competitive priorities, it was ascertained that compliance with laws and standards has a greater influence on the performance of competitive priorities, followed by society's demands, consumption of natural resources and, finally, the prevention of impacts.

Another conclusion is that all environmental dimension performance indicators have a strong influence on the performance of company image.

Finally, the study revealed that the companies have introduced the environmental dimension in their operations strategy and, as a result, have dealt with the environment as one of their competitive priorities. When the environmental subject is considered a priority, the companies define objectives and actions intended to improve the environmental performance indicators that, by their turn, directly impact the operations performance. So the inclusion of the environment as one of the das competitive priorities can be seen as an extension of the view of the main operations strategy authors, who have only considered the competitive priorities of quality, reliability, flexibility and cost.

It is worth mentioning that two companies have also considered, in addition to the environment, occupational safety as a competitive priority, possibly anticipating a future trend for the increase in the coverage of the environmental issue involving sustainability. This more systemic and more sustainable perspective affects the operations strategy in the sense of searching solutions beyond the topics of energy sources, saving resources, replacement and use of consumables and mitigation of environmental impacts along the value chain. Using the perspective of sustainability, the companies have designed socially more fair production systems, where occupational safety and occupational health are seen as a strategic aspect that contributes to the competitive performance of the operations field.

A contribution of this article, from the theoretical point of view, is the proposal of a conceptual model to fill a gap in literature, regarding the lack of alignment between operations strategy theories and environmental management, which can make more difficult, or even underestimate, understanding of the role of the operations field in the search for competitive advantage.

Considering the restrictions made to the case study method, we suggest that future research must validate, from a statistics point of view, the conceptual model proposed also in other production sectors. Another possibility would be to carry out case studies in other companies from the automotive chain.

\section{References}

Alfred, A. M., \& Adam, R. F. (2009). Green management matters regardless. The Academy of Management Perspectives, 23(3), 17-26.

Angell, L. C. \& Klassen, R. (1999). Integrating environmental issues into main stream: an agenda for research in operation management. Journal of Operation Management, 17(5), 575-598.

Associação Brasileira De Normas Técnicas. (2004). NBR ISO 14031: indicadores de desempenho ambiental operacional. Rio of Janeiro. 
Barnes, D. (2001). Research methods for the empirical investigation of the process of formation of operations strategy. International Journal of Operations \& Production Management, 21(8), 1076-1095.

Campos, L. M. D. S., \& Melo, D. A. D. (2008). Indicadores de desempenho dos Sistemas de Gestão Ambiental (SGA): uma pesquisa teórica. Production Journal, 18(3), 540-555.

Collis, J., Hussey, R., Crowther, D., Lancaster, G., Saunders, M., Lewis, P. \& Johnson, P. (2003). Business research methods.

Gavronski, I. (2012). Resources and Capabilities for Sustainable Operations Strategy. Journal of Operations and Supply Chain Management, 1(1), $1-20$.

Gil, A. C. (1999). Métodos e técnicas de pesquisa social. São Paulo, Atlas, 1999.

Govidan, K.; Kaliyan, M.; Kannan, D.\& Haq, A. (2014). Barriers analysis for green supply chain management implementation in Indian industries using analytic hierarchy process. Int. Journal of Production Economics 147 555-568.

Gupta, M. C. (1995). Environmental management and its impact on the operations function. International Journal of Operations \& Production Management, 15(8), 34-51.

Hayes, R. H., \& Pisano, G. P. (1996). Manufacturing strategy: at the intersection of two paradigm shifts. Production and operations management, 5(1), 25-41.

Hayes, R. H., \& Wheelwright, S. C. (1984). Restoring our competitive edge: competing through manufacturing, Wiley, New York, 1984.

Hsu, C. C., Choon Tan, K., Hanim Mohamad Zailani, S. \& Jayaraman, V., (2013). Supply chain drivers that foster the development of green initiatives in an emerging economy. International
Journal of Operations \& Production Management, 33(6), 656-688.

Jabbour, C.; Teixeira, A.; Jabbour, A. \& Freitas, W. (2012). "Verdes e Competitivas?" A influencia da gestão ambiental no desempenho operacional de empresas brasileiras. Ambiente \& Sociedade. XV(2), 151-172.

Jacobs, B. W., Singhal, V. R., \& Subramanian, R. (2010). An empirical investigation of environmental performance and the market value of the firm. Journal of Operations Management, 28(5), 430-441.

Jiménez, J., \& Lorente, J. J. (2001). Environmental performance as an operations objective. International Journal of Operations \& Production Management, 21(12), 1553-1572.

Lowson, R. H. (2003). The nature of an operations strategy: combining strategic decisions from the resource-based and market-driven viewpoints. Management Decision, 41(6), 538-549.

Maia, J. L., Cerra, A. L., \& Alves Filho, A. G. (2005). Inter-relações entre estratégia de operaçôes e gestão da cadeia de suprimentos: estudos de caso no segmento de motores para automóveis. Gestão \& Produçâo, 12(3), 377-391.

Sanches, C. S. (2000). Gestão ambiental proativa. Revista de Administração de Empresas, 4O(1), 76-87.

Sarkis, J. (2001). Manufacturing's role in corporate environmental sustainability-Concerns for the new millennium. International Journal of Operations \& Production Management, 21(5/6), 666-686.

SILVA, E. D. (2008). O relacionamento entre estratégia de manufatura, práticas de produção e desempenho operacional e de negócios: uma survey em firmas do setor moveleiro. 2008 (Doctoral dissertation, Tese (Doutorado)-Escola de Engenharia de São Carlos da Universidade de São Paulo. São Carlos: UFSCar). 
Skinner, W. (1969). Manufacturing - Missing Link in Corporate Strategy, Harvard Business Review, May-June 1969.

Slack, N. \& Lewis, M. (2001). Operations Strategy. New Jersey, Prentice-Hall.

Srivastava, S. (2007). Green supply-chain management: a state-of-the-art literature review. International Journal of Management Reviews, 9 (1), 53-80.

Thomaz, J. C., \& Brito, E. P. Z. (2010). Reputação Corporativa: Construtos Formativos e Implicaçôes para a Gestão/Corporate Reputation: Formative Constructs and Implications for Management. Revista de Administração contemporânea, 14(2), 229.

Ventura, M. M. (2007). O estudo de caso como modalidade de pesquisa. Rev Socerj, 20(5), 383-6.
Voss, C. A. (1995). Alternative paradigms for manufacturing strategy.International Journal of Operations \& Production Management, 15(4), 5-16.

Voss, C. A. (2005). Alternative paradigms for manufacturing strategy.International Journal of Operations \& Production Management, 25(12), 1211-1222.

Voss, C., Tsikriktsis, N., \& Frohlich, M. (2002). Case research in operations management. International journal of operations \& production management,22(2), 195-219.

Womack, J. P., \& Jones, D. T. (2004). A máquina que mudou o mundo. Gulf Professional Publishing.

Yin, R. K. (2010). Estudo de Caso: planejamento e métodos, tradução Ana Thorell, revisão técnica Cláudio Damacena.

\section{About the authors:}

1. Gabriela Scur, PhD in Industrial Engineering, University of Sao Paulo, Polytechnic School, Sao Paulo, SP, Brazil. E-mail: gabriela@fei.edu.br.

2. Guilherme Heinz, Msc in Mechanical Engineering, University Center FEI, Sao Paulo, SP, Brazil. E-mail:guilherme.heinz@me.com.

\section{Contribution of each author:}

\begin{tabular}{lcc}
\hline Contribution & Gabriela Scur & Guilherme Heinz \\
\hline 1. Definition of research problem & $\sqrt{ }$ & $\sqrt{ }$ \\
2. Development of hypotheses or research questions (empirical studies) & $\sqrt{ }$ & $\sqrt{ }$ \\
3. Development of theoretical propositions (theoretical Work) & $\sqrt{ }$ & $\sqrt{ }$ \\
4. Theoretical foundation/ Literature review & $\sqrt{ }$ \\
5. Definition of methodological procedures & $\sqrt{ }$ \\
6. Data collection & $\sqrt{ }$ \\
7. Statistical analysis & $\sqrt{ }$ \\
8. Analysis and interpretation of data & $\sqrt{ }$ \\
9. Critical revision of the manuscript & $\sqrt{ }$ \\
10. Manuscript Writing & $\sqrt{ }$ \\
11. Other (Adaptations from evaluations) & $\sqrt{ }$ \\
\hline
\end{tabular}

